AJAR

7,3

Received 23 November 2020 Revised 30 January 2021 10 March 2021

27 April 2021

Accepted 9 May 2021

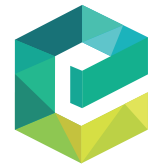

Asian Journal of Accounting Research

Vol. 7 No. 3, 2022 pp. 230-251

Emerald Publishing Limited 2443-4175

DOI 10.1108/AJAR-11-2020-0121

\section{The effect of audit committee quality on the conventional and Islamic banks' financial performance between subprime and Corona crises}

\author{
Achraf Haddad \\ Faculty of Economic Sciences and Management of Sousse, University of Sousse, \\ Sousse, Tunisia and \\ Faculty of Economic Sciences and Management of Sfax, University of Sfax, \\ Sfax, Tunisia \\ Anis El Ammari \\ Faculty of Economic Sciences and Management of Mahdia, University of Monastir, \\ Monastir, Tunisia, and \\ Abdelfattah Bouri \\ Faculty of Economic Sciences and Management of Sfax, University of Sfax, \\ Sfax, Tunisia
}

\begin{abstract}
Purpose - This study aims to test empirically the differences between Islamic and conventional banks in terms of impacts of the audit committees' quality on financial performance between Subprime and Corona crises.

Design/methodology/approach - The variables are articulated in four hypotheses tested by the GLS analysis. The data were collected via DATASTREAM and from banks' annual reports. The collected data covered four continents: America, Asia, Africa and Europe. The financial performance measures and audit committee's determinants of the conventional and Islamic banks concerned 112 banks of each type after the Subprime crisis and before the Corona crisis (2010-2019).

Findings - Results showed that the audit committee reduced the profitability of two bank types. Moreover, it harmed the conventional banks' efficiency, but reported an unclear effect within Islamic banks. Even so, the authors noticed that the audit committee had a positive impact for the conventional banks' liquidity, while the same effect was apparently ambiguous on the Islamic banks' liquidity. For solvency, the audit committee positively influenced conventional banks, while it affected that of Islamic banks.

Research limitations/implications - Empirically, the authors' results can serve as a reference for decisionmakers allowing to clarify the data on the financial competitiveness of two bank types to facilitate the planning of strategic performance programs based on the audit committee quality. Theoretically, researchers found that the differences between the results are due to the audit committee quality of each bank type or to the financial performance evaluation method. However, there are further factors that are related to the research peculiarities, the methodology, the data and the interpretation.
\end{abstract}

JEL Classification - F39, G1, G20, G21, G30, G33.

(C) Achraf Haddad, Anis El Ammari and Abdelfattah Bouri. Published in Asian Journal of Accounting Research. Published by Emerald Publishing Limited. This article is published under the Creative Commons Attribution (CC BY 4.0) licence. Anyone may reproduce, distribute, translate and create derivative works of this article (for both commercial and non-commercial purposes), subject to full attribution to the original publication and authors. The full terms of this licence may be seen at http:// creativecommons.org/licences/by/4.0/legalcode

The authors would like to express their gratitude to the editor and the reviewers who have significantly contributed to the improvement of the research quality thanks to their recommendations and helpful comments. 
Originality/value - Based on the comparative literature review between conventional and Islamic banks, this study is the first conditional and comparative research between the audit committee quality and the financial performance of conventional and Islamic banks in a specific period (after Subprime and before Corona crises).

Keywords Conventional banks (CBs), Islamic banks (IBs), Audit committee quality (ACQ), Financial performance (FP), Comparative study, Financial stability period

Paper type Research paper

\section{Introduction}

As a mechanism of governance, the audit committee (AC) was defined by the US Financial Security Act (Sarbanes-Oxley) as being "an independent advisory body established by and within the board of directors, primarily responsible for overseeing the accounting process, control the financial information and auditing the financial statements. Thus, it is engaged in the services of the board, the remuneration and the control of the auditors' works." Referring to the law (Sarbanes-Oxley Act, 2002), the AC is a body responsible for appointing, remunerating, retaining and supervising the work of internal and external auditors. It is responsible for strengthening the independence of audit functions through the review of financial statements and the assessment of risks and vulnerabilities.

In the literature, the ACs' effectiveness has been the subject of various studies. Some highlighted the impact of audit committee quality (ACQ) on the governance quality (Moses et al., 2016; Zalata et al., 2018), while in others, the empirical results agree on the effect of ACs on FP (Bilal et al., 2018; Aminul et al., 2018). Given its role in monitoring and controlling management activities, the AC applies the necessary corrective actions in the case of fraud. However, Gul (1989) indicated that the existence of an AC does not improve the auditor's perception of independence. Besides that, Vienot (1995) and Bouton (2002) criticized the presence of an AC within companies and confirmed that the AC had no effective activities within the company.

Several studies have tested the relationship between the presence of an AC, the financial reporting quality and the financial statements transparency (Dinu and Nedelcu, 2015; Bouaine and Hrichi, 2019). In other words, AC research produced senior management, financial information quality, and it showed a positive impact on the governance quality before, during and after the Subprime crisis (Alzoubi and Selamat, 2012). Indeed, corporate oversight by a highquality committee can reduce the financial statements' falsification and earnings' management (Beasley, 1996). Other studies discussed the role of the AC in reducing agency costs between the CEO [1] and the chairman to solve conflicts of interest as a priority to achieve the objective of improving the governance quality (Collier and Gregory, 1999). The primary function of the AC is to monitor information related to FP (Xie et al., 2003). In the same vein, Chen et al. (2015) revealed that companies that had established ACs without considering shareholders' primacy have more advantages to improve their benefits' quality. However, in favor of agency theory, if the number of auditors was large, the company would realize a poor FP.

The $\mathrm{AC}$ within banks plays a dual role. On the one hand, members are responsible for monitoring the creation of monetary value, protecting the wealth of banks, ensuring the effectiveness of governance practices, and managing banks' potential conflicts of interest. On the other hand, it also serves as a governance mechanism that aligns the interests of executives with those of shareholders. The interest of the AC effectiveness in a financial environment is not stable and suffers from a governance crisis. Therefore, the need to set up this body within banks has increased dramatically, especially after the Subprime crisis. The existence of an AC is mandatory for listed companies and banks (Darmadi, 2013b).

The choice of this period is justified, given that this decade was characterized by a stability of the world banking system, allowing us to provide more effective comparative results that better reflect the real differences of the ACs' impacts on one bank type compared to the other. Thus, this period shows the added value of each AC on the FP compared to the same impacts for the other bank types. The first target of our explanatory research is to study

The effect of audit committee quality 
the reached relationship between a set of FP measures and some ACQ determinants for both conventional and Islamic banks. The second purpose is to select the best AC model based on the comparison between the AC's effects as a governance mechanism on the profitability, efficiency, liquidity and solvency of each bank type.

Since there are no comparative studies conducted in this area specifically among banks on the international scale, this study will broaden the scope by providing theoretical and empirical evidence of the relationship between various $\mathrm{AC}$ characteristics and $\mathrm{FP}$ in a specific period. Our second contribution is directing the choice of the preferred AC based on, among various factors, all functions, activities, tasks and managers. The basis for sorting and channeling data is based on historical information (accounting data, audit reports, bank structure and other information). We synthesized the third contribution to the effective constitution and management of the $\mathrm{AC}$ to maintain the $\mathrm{FP}$ of the conventional or Islamic banks and facilitate their introductions into a new market, the expansion of their activities, the launch of a new banking product, and FP improvement. In the fourth contribution, we showed that the good AC's structure guarantees not only the supervision of banks' FPs, but also mitigated the agency conflict concerning FP between stakeholders and all types of incoming and outgoing governance flows related to all aspects of financial, accounting, audit and control information, whatever the operational, technical, or behavioral differences between the supervisors and managers may be.

\section{Literature review and hypothesis development}

Stakeholder theory considers ethics through the integration of human values into operational management, functions, directions, regulations and control. This theory encompasses the relationship between all stakeholders threatened by the opportunism of some of them. This can affect the institutions' performance that benefits from the return via the exploitation of human and financial resources, namely shareholders, managers, creditors, employees, customers, suppliers and the government (Himaj, 2014). The presence of an AC causes the reliability of financial reports to improve FP. In the following, our choice of the AC's determinants focuses on the impact of the $\mathrm{AC}$ size, the expertise of its members, their degree of independence, and the number of annual meetings held by the AC (Bryan et al., 2004) on the FP of conventional and Islamic banks. This choice was justified by three reasons. First, because these characteristics related directly to the ACs' auditors. Second, because these measures were the most readily available compared with the other criteria. Finally, the impacts of these determinants on the FP were quantifiable and visible; therefore, we could maximize the number of significant impacts.

\subsection{Audit committee size}

Several previous studies highlighted the effect of the AC size on FP (Krishnan, 2005; Dinu and Nedelcu; 2015; Tarek and Mohamed, 2016). The first set of studies observed a positive association between the AC size and the FP (Awinbugri and Prince, 2019; Sattar et al., 2020; Ashari and Krismiaji, 2020). In this sense, Anderson et al. (2004) and Krishnan and Lee (2009) showed that the presence of a large AC provided strong oversight, improved the governance quality, and promoted the disclosure and the transparency degree. Along the same lines, Wan et al. (2010) found that the larger the ACs' sizes, the more information on the governance quality would be available to the users of financial statements. Hence, this positively and directly influenced profits. Other studies stated that the larger the ACs' sizes, the less adjusted the results would be (Cornett et al., 2009).

However, the second set of studies found a negative association between the governance issues and the AC size (Krishnan, 2005). Based on the stakeholder theory, a large AC generates more delegation of power among members. Nevertheless, this habit creates neglect and delay of duty, which causes more opportunistic behavior within the AC. For example, 
Anderson et al. (2004) revealed that the $\mathrm{AC}$ size and the number of $\mathrm{AC}$ meetings were negatively correlated and associated with the performance gaps. Another study found that the AC size systematically influenced the downward management of revenues (Cornett et al., 2009). Likewise, Xie et al. (2003) reported that small ACs tend to be more participatory, since they are characterized by a higher oversight capacity than larger ACs. Furthermore, Indrawan et al. (2018) and Baiden (2020) revealed that a company with a smaller AC size tended to improved income smoothing practices due to lower supervision in the financial reporting process.

Based on the previous studies dealing with the relationship between the variables mentioned, our testable proposition is as follows:

H1. There is a negative correlation between the $\mathrm{AC}$ size and the $\mathrm{FP}$ of conventional and Islamic banks.

\subsection{Presence of an accountant, a financier or an auditor in the audit committee}

The effectiveness of an $\mathrm{AC}$ is one of the main criteria for audit quality. It is highly dependent on a socio-psychological process and the personal and professional qualification of the members. In particular, the AC effectiveness also depends on stakeholder groups that have influential interactions, exchangers of information, and interactions with $\mathrm{AC}$ members and internal or external auditors. The behavioral and technical competence of directors directly influences the audit quality, as the most competent directors and experienced directors who invest more in professional development. According to the Sarbanes-Oxley Act (2002), all AC members must have knowledge of financial reports, answers to audit questions and internal control experience. At least one member among the $\mathrm{AC}$ should be a financial expert with ongoing experience in accounting. The experience includes covering accounting estimates, accruals, provisions, preparation of financial statements, and auditing financial information. Yet, Bilal et al. (2018) gave the implication of the need to have at least two financial experts within the $\mathrm{AC}$ and the obligation of its strengthening.

However, Tanyi and Smith (2015) concluded that the excessive engagement of AC members had a negative and significant impact on the supervision quality and the financial information quality. Companies that have experienced members on their ACs and abnormally high-profit accumulation levels are more likely to exceed performance benchmarks. Krishnan (2005) discovered the presence of four factors indirectly associated with the $\mathrm{AC}$ that may have an impact on internal control: managers' work experience, the tendency of management to commit fraud, the permanence of auditors, and financial stress. As a result, the $\mathrm{AC}$ characteristics are associated with internal control only after the control of other governance bodies. Thus, the AC contribution to internal control extends beyond other organizations.

In the same research line, Abbott et al. (2004) revealed the presence of a negative relationship between $\mathrm{AC}$ expertise and errors detected in the financial statements. This role of $\mathrm{ACs}$ has provided a new research line on the relationship between the $\mathrm{AC}$ and internal control. Confirming the same idea with the Malaysian perspective, Saad et al. (2007) affirmed the presence of a negative association between the AC members' expertise and the detection of discretionary accruals. AC expertise has a negative and significant impact on non-audit fees (Chaudhry, 2013).

Indeed, Krishnan (2005) confirmed that ACs whose members have financial expertise, are more likely to be exposed to the impacts of internal control problems. Empirically, he concluded that after the change of auditors, there were companies that had disclosed all the internal control problems while they had, intentionally, kept other problems.

Similarly, Carrera et al. (2017) found that the proportion of experts within ACs decreased the FRQ. According to them, the AC members' financial expertise could enhance their
The effect of audit committee quality 
responsibilities provide shareholders with the control process and provide sufficient assurance of independent auditing (Deloitte, 2007). Besides that, a significant number of external auditors facilitates the dispersal of administrators' attention during the discussion of missions and tasks (Krishnan, 2005). Some researchers expect that the proportion of independent directors on the $\mathrm{AC}$ allows the latter to improve the quality of the preparation process of the financial statements of conventional and Islamic banks. As a result, this policy of selecting auditors stimulates increased reliability of the financial statements. Another current showed that the level of AC independence was positively associated with the financial information quality (Mangena and Tauringana, 2007) and negatively related to the propensity to manage the outcome (Abbott et al., 2004).

Other studies concluded that the ACs' independence had a positive influence on accounting restatements, abnormal regularizations of their profits, and the interests of owners against management conflicts (Assenga et al., 2018). Recently and similarly, Poretti et al. (2018) stated that higher AC independence increased the autonomy of their declarations and encouraged market reactions to the announcements of results.

After the variant exposure of the results found in the governance literature, we tested the proposition of the following hypothesis:

H3. There is a positive correlation between the percentage of independent directors within the AC and the FP of conventional and Islamic banks.

\subsection{Number of meetings held by the audit committee}

The number of meetings as a determinant of the ACQ showed that it was the best indicator of the effectiveness of this governance body (Abbott et al., 2004; Gendron and Bedard, 2006). Many studies focused on the effect of the number of meetings on the FP (Dinu and Nedelcu; 2015; Shahkaraiah and Amiri, 2017). This association gives more importance to the effect of this determinant in the precision of the ACQ and questions the impact of the number of meetings held by the ACs of the conventional and Islamic banks on their FPs.

Several previous studies concluded that there was a negative correlation between the number of meetings held and FP (Aminul et al., 2018; Awinbugri and Prince, 2019). In this line of research, Cornett et al. (2009) tested the association between the number of AC meetings and the performance effectiveness of Thai non-life insurance companies for the period of (2000-2007). It revealed the existence of a negative impact between the number of AC meetings and the FP effectiveness. Moreover, Aminul et al. (2018) examined the effect of board characteristics on the quality of earnings, moderated by the audit quality and the ownership concentration. In this study, the board of directors' effectiveness was measured by the AC's determinants. They considered the AC to be complementary to the board's role in monitoring the profit report. They revealed that the number of $\mathrm{AC}$ meetings had a negative impact on the results' quality (Awinbugri and Prince, 2019).

From what is already stated in the literature, our hypothesis is as follows:

H4. The number of meetings held by the AC has a negative impact on the FP of conventional and Islamic banks.

\section{Empirical method}

To choose the bank model that had the most qualified AC for improving FP, we used the conditional method of collecting and filtering samples. For that, we selected only the full observations, which allowed us to generalize the new results. Because of the existence of autocorrections in three conventional models and two Islamic models (Tables 2 and 3), to embody this comparison, we used the GLS technique, which was the most convenient method to obtain the best comparison between the impacts, allowing us to overcome the constraints between the variables.
The effect of audit committee quality 


\section{AJAR 7,3}

236

\subsection{Methodological aspects}

To answer the questions already posed in our hypotheses, the following plan was observed: we started with the presentation of data, then we stated our study variables, and finally, we exhibited our models.

3.1.1 Data collection. From two independent populations, two independent samples consisting of 683 Islamic financial institutions and 2,974 conventional financial institutions were taken. Samples were collected from 30 countries between 2010 and 2019, but we ignored all financial institutions guided by specific standards. The selected samples contained only fully Conventional or Islamic banks. In addition, we shut out all observations containing missing data, as well as banks with various typical statuses. Although our objective was to obtain two equal samples, we proceeded to filter several of them based on qualitative and quantitative criteria (e.g., activity type, bank width, similarity of home country, samples equality) until each IB had a similar CB in the same country. Finally, we obtained two equal samples, each containing 1,120 observations (bank/ year). The banks are located in Algeria (3), Bahrain (6), Bangladesh (4), Canada (1), Egypt (4), France (2), India (2), Indonesia (4), Jordan (4), Kazakhstan (3), Kuwait (6), Lebanon (2), Luxembourg (2), Malaysia (7), Nigeria (2), Oman (3), Pakistan (8), Qatar (6), Saudi Arabia (9), Senegal (3), Singapore (4), South Africa (1), Sri Lanka (1), Sudan (5), Thailand (1), Tunisia (2), Turkey (5), United Arab Emirates (5), United Kingdom (5), and USA (2). Since we worked with a conditional method, we extended the field of selection of observations to four continents, firstly to aggravate the samples' sizes and secondly to obtain representative and suitable results for the generalization.

3.1.2 Modeling variables. 3.1.2.1 Variables to explain. As we have already mentioned, the variable we wanted to explain was FP. This variable was symbolized by four measurable parameters which were profitability, efficiency, liquidity and solvency. Table 4 summarizes the measures' characteristics.

3.1.2.2 Explanatory variables. The FPs of conventional and Islamic banks were explained by four AC determinants. Table 5 provides a detailed description of each variable.

3.1.2.3 Control variables. In order to control the partial effects of the basic variables, we added four control variables to our models. Table 6 defines the targeted variables that we saw based on the literature review, that could have an impact on the banks' FP.

\begin{tabular}{|c|c|c|c|c|c|}
\hline Model type & Wooldridge test & Durbin Watson test & $F$ & $\operatorname{Pr}$ & Decision \\
\hline $\operatorname{LnProc}_{i t}$ & Wooldridge test & - & 12.097 & $0.0014<5 \%$ & Presence of autocorrelation \\
\hline Effc $_{i t}$ & - & Durbin Watson test & 50.482 & $0.0000<5 \%$ & Presence of autocorrelation \\
\hline Liqc $_{i t}$ & Wooldridge test & - & 21.187 & $0.0001<5 \%$ & Presence of autocorrelation \\
\hline LnSolc $_{i t}$ & Wooldridge test & - & 1.709 & $0.1988>5 \%$ & Absence of autocorrelation \\
\hline
\end{tabular}

Source(s): https://drive.google.com/file/d/1ehyi5wfDNzRrzsQC0jUloukFuZxCTuC-/view
Table 2.

Autocorrelation tests of the $\mathrm{CBs} /$ model

\begin{tabular}{|c|c|c|c|c|c|}
\hline Model type & Wooldridge test & Durbin Watson test & $F$ & $\operatorname{Pr}$ & Decision \\
\hline $\operatorname{LnProi}_{i t}$ & - & Durbin Watson test & 58.695 & $0.0000<5 \%$ & Presence of autocorrelation \\
\hline Effi $_{i t}$ & - & Durbin Watson test & 1.302 & $0.2609>5 \%$ & Absence of autocorrelation \\
\hline Liqi $_{i t}$ & Wooldridge test & - & 0.096 & $0.7577>5 \%$ & Absence of autocorrelation \\
\hline LnSoli $_{i t}$ & Wooldridge test & - & 87.514 & $0.0000<5 \%$ & Presence of autocorrelation \\
\hline
\end{tabular}

Source(s): https://drive.google.com/file/d/1ehyi5wfDNzRrzsQC0jUloukFuZxCTuC-/view 
3.1.3 Models to estimate. In accordance with the objective of our research, this tool gave us partial impacts from each submodel of each FP measure. We then compared the effects of each submodel and each bank type with the same determinants' impacts of their counterparts. In what follows, we expose the complete models to be estimated.
The effect of audit committee quality

\begin{tabular}{|c|c|c|c|c|}
\hline FP measurement & $\begin{array}{l}\text { CBs' } \\
\text { rating }\end{array}$ & $\begin{array}{l}\text { IBs' } \\
\text { rating }\end{array}$ & Measurement & References \\
\hline $\begin{array}{l}\text { Profitability } \\
\text { ratio }\end{array}$ & Proc & Proi & Marginal profit/total revenues & $\begin{array}{l}\text { Ogbeide and Akanji } \\
\text { (2018) }\end{array}$ \\
\hline Liquidity ratio & Liqc & Liqi & Net loans/total assets & Elsiefy (2013) \\
\hline Efficiency ratio & Effc & Effi & $\begin{array}{l}\text { Operating result/average total } \\
\text { assets }\end{array}$ & Emilia and Judit (2012) \\
\hline Solvency ratio & Solc & Soli & Total loans/total deposits & Norhidayah et al. (2011) \\
\hline
\end{tabular}

Source(s): https://drive.google.com/file/d/1KghOXuplGFJ4SzKpBSvgCsOXoLwvtaAZ/view

Table 4.

Description of the variables to explain

\begin{tabular}{|c|c|c|c|c|}
\hline $\begin{array}{l}\text { The internal } \\
\text { governance } \\
\text { mechanism }\end{array}$ & CBs' rating & IBs' rating & Measurement & References \\
\hline \multirow[t]{4}{*}{ Audit committee } & $\begin{array}{l}\text { Size of the CB's AC } \\
\text { (TCOMc) }\end{array}$ & $\begin{array}{l}\text { Size of the IB's AC } \\
\text { (TCOMi) }\end{array}$ & $\begin{array}{l}\text { Number of directors or } \\
\text { auditors in the AC }\end{array}$ & $\begin{array}{l}\text { Thu et al. } \\
\text { (2016) }\end{array}$ \\
\hline & $\begin{array}{l}\text { Competence of the } \\
\text { CB's AC } \\
\text { (PRESEXPc) }\end{array}$ & $\begin{array}{l}\text { Competence of the } \\
\text { IB's AC } \\
\text { (PRESEXPi) }\end{array}$ & $\begin{array}{l}\text { Binary variable } \\
1 \text { : if there is an } \\
\text { accountant, a financier } \\
\text { or an auditor on the AC } \\
0 \text { : if not }\end{array}$ & $\begin{array}{l}\text { Bilal et al. } \\
\text { (2018) }\end{array}$ \\
\hline & $\begin{array}{l}\text { Independence of the } \\
\text { CB's AC (INDCOMc) }\end{array}$ & $\begin{array}{l}\text { Independence of the } \\
\text { IB's AC (INDCOMi) }\end{array}$ & $\begin{array}{l}\text { Number of independent } \\
\text { directors in the AC }\end{array}$ & $\begin{array}{l}\text { Bilal et al. } \\
\text { (2018) }\end{array}$ \\
\hline & $\begin{array}{l}\text { Number of the AC } \\
\text { meetings of the CB } \\
\text { (REUCOMc) }\end{array}$ & $\begin{array}{l}\text { Number of the AC } \\
\text { meetings of the IB } \\
\text { (REUCOMi) }\end{array}$ & $\begin{array}{l}\text { Number of meetings } \\
\text { held by the AC during a } \\
\text { year }\end{array}$ & $\begin{array}{l}\text { Cornett et al. } \\
\text { (2009) }\end{array}$ \\
\hline
\end{tabular}

Source(s): https://drive.google.com/file/d/1F6DJsbmKGGRZbv1umxUSSYllyx7WwHPR/view

Table 5.

Description of the explanatory variables

\begin{tabular}{|c|c|c|c|c|}
\hline $\begin{array}{l}\text { Control } \\
\text { variable }\end{array}$ & $\begin{array}{l}\text { CBs' } \\
\text { rating }\end{array}$ & $\begin{array}{l}\text { IBs' } \\
\text { rating }\end{array}$ & Measurement & References \\
\hline Bank type & TYc & TYi & $\begin{array}{l}\text { A qualitative variable that takes three modalities } \\
\text { (1) if the bank is commercial } \\
\text { (2) if the bank is investment } \\
\text { (3) if the bank is universal }\end{array}$ & Thomi (2014) \\
\hline Bank age & AGc & AGi & $\begin{array}{l}\text { Age of the Islamic or conventional bank for each } \\
\text { year }\end{array}$ & Arif et al. (2017) \\
\hline Bank size & TAc & TAi & $\begin{array}{l}\text { Logarithm of the total assets of Islamic or } \\
\text { conventional bank }\end{array}$ & $\begin{array}{l}\text { Rashid et al. } \\
(2020)\end{array}$ \\
\hline Inflation & $\mathrm{INFC}$ & INFi & $\begin{array}{l}\text { The inflation rate in the country of origin of the } \\
\text { Islamic or conventional bank }\end{array}$ & $\begin{array}{l}\text { Nahar and Sarker } \\
(2016)\end{array}$ \\
\hline
\end{tabular}

Source(s): https://drive.google.com/file/d/1yvMlc6HMxMxCAod6ix2clXqveNCgA2IZ/view

Table 6.

Description of control variables 
AJAR

7,3

238
Conventional multiple regression is:

Association between FP measures of CBs and ACQ:

$$
\begin{aligned}
Y c_{i t}= & \alpha_{0}+\alpha_{1} \operatorname{LnTCOMc}_{i t}+\alpha_{2} \operatorname{LnPRESEXPc}_{i t}+\alpha_{3} \operatorname{LnINDCOMc}_{i t} \\
& +\alpha_{4} \operatorname{LnREUCOMc}_{i t}+\alpha_{5} \mathrm{TYc}_{i t}+\alpha_{6} \operatorname{LnAGc}_{i t}+\alpha_{8} \operatorname{LnINFc}_{i t}+\varepsilon_{i t}
\end{aligned}
$$

$Y c_{i t}$ can be (LnProc $i t$, Effc $_{i t}$, Liqc $_{i t}$, LnSolc $\left._{i t}\right)$

Islamic multiple regression is:

Association between FP measures of IBs and ACQ:

$$
\begin{aligned}
Y i_{i t}= & \beta_{0}+\beta_{1} \operatorname{LnTCOMi}_{i t}+\beta_{2} \operatorname{LnPRESEXPi}_{i t}+\beta_{3} \mathrm{LnINDCOMi}_{i t} \\
& +\beta_{4} \mathrm{LnREUCOMi}_{i t}+\beta_{5} \mathrm{TYi}_{i t}+\beta_{6} \mathrm{LnAGi}_{i t}+\beta_{8} \mathrm{LnINFi}_{i t}+\varepsilon_{i t}
\end{aligned}
$$

$\mathrm{Yi}_{i t}$ can be $\left(\right.$ LnProi $_{i t}$, Effi $_{i t}$, Liqi $i_{i t}$, LnSoli $\left._{i t}\right)$

3.2 Multivariate analysis: regressions stability test (Chow test (Appendix) [2])

Tables 7-18 show the results of the Chow test for each FP measurement, as well as the results of the two unique models from each sample.

3.2.1 Model of the AC effects on the banks' profitability. From the analysis of variance test, we retained that the calculated Fisher statistics (CFS) was greater than the tabulated statistics,

\begin{tabular}{lccccc}
\hline Source & Degree of freedom & Sum of squares & Average squares & $F$ & $\begin{array}{c}\text { Sig } \\
\text { Prob }>F\end{array}$ \\
\hline Model LnPro & & & & & \\
Residuals & 8 & 54.1659753 & 6.77074691 & 8.56 & 0.0000 \\
Total & 2,002 & 277.63748 & 0.790989973 & - & - \\
\end{tabular}

ANOVA $^{\mathrm{a}}$ test of the overall sample profitability

Note(s): ${ }^{a}$ ANOVA $=$ analysis of variance

\begin{tabular}{|c|c|c|c|c|c|}
\hline Source & Degree of freedom & Sum of squares & Average squares & $F$ & $\begin{array}{c}\text { Sig } \\
\text { Prob }>F\end{array}$ \\
\hline Model LnProc $i t$ & 8 & 42.8148672 & 5.3518584 & 6.57 & 0.0000 \\
\hline Residuals & 994 & 152.44223 & 0.815199089 & - & - \\
\hline Total & 1,004 & 195.257097 & 1.00131845 & - & - \\
\hline \multicolumn{6}{|c|}{ Source(s): https://drive.google.com/file/d/18I_cxB4clZcK9QqDFusb7iuoUYZIHVm3/view } \\
\hline
\end{tabular}

Source(s): https://drive.google.com/file/d/18I_cxB4clZcK9QqDFusb7iuoUYZIHVm3/view

\begin{tabular}{|c|c|c|c|c|c|}
\hline Source & Degree of freedom & Sum of squares & Average squares & $F$ & $\begin{array}{c}\text { Sig } \\
\text { Prob }>F\end{array}$ \\
\hline Model LnProi ${ }_{i t}$ & 8 & 32.7361929 & 4.09202411 & 6.33 & 0.0000 \\
\hline Residuals & 885 & 100.248411 & 0.646763944 & - & - \\
\hline Total & 993 & 132.984604 & 0.815856467 & - & - \\
\hline \multicolumn{6}{|c|}{$\begin{array}{l}\text { Note(s): } N=2,224 \text { and } k=9 \\
\text { Fp } \rightarrow(9 ; 2,206) \\
\text { Fcp }=\frac{\text { RSS }-(\text { RSS1+RSS })}{\text { RSS1+RSS2 }} * \frac{N-2 k}{k}=\frac{277.637-(152.442+100.248)}{(152.442+100.248)} * \frac{2224-(2 * 9)}{9}=24.198>1.59 \\
\text { where Fcp: } F \text { calculated of the profitability } \\
\text { Source(s): https://drive.google.com/file/d/18I_cxB4clZcK9QqDFusb7iuoUYZIH }\end{array}$} \\
\hline
\end{tabular}

ANOVA test of the CBs' profitabilities
Table 9.

ANOVA test of the IBs' profitabilities 
so we accepted the stability hypothesis. We concluded that the $\mathrm{AC}$ coefficients relating to the profitability-specific models of the conventional and Islamic banks were unalterable.

3.2.2 Model of the AC effects on the banks' efficiency. The analysis of variance test indicated that the CFS was greater than the tabulated statistics, for which we accepted the null hypothesis. We approved that the $\mathrm{AC}$ coefficients relating to the efficiency-specific models of conventional and Islamic banks were stable.

3.2.3 Model of the AC effects on the banks' liquidity. Analysis of variance showed that the CFS was greater than the tabulated statistics, in which case we adopted the null hypothesis. We confirmed that the $\mathrm{AC}$ coefficients relative to the liquidity-specific models of the conventional and Islamic banks were stable.
The effect of audit committee quality

\begin{tabular}{lccccc}
\hline Source & Degree of freedom & Sum of squares & Average squares & $F$ & $\begin{array}{c}\text { Sig } \\
\text { Prob }>F\end{array}$ \\
\hline Model Eff & & & & & \\
Residuals & 8 & 65.1302574 & 8.14128217 & 6.94 & 0.0000 \\
Total & 1,996 & 402.399295 & 1.17317579 & - & - \\
\end{tabular}

Source(s): https://drive.google.com/file/d/1EAolqaSq069gmyItAaombSFxEraziqLb/view

Table 10.

ANOVA test of the overall sample efficiency

\begin{tabular}{lccccc}
\hline & & & & \multicolumn{2}{c}{ Sig } \\
Source & Degree of freedom & Sum of squares & Average squares & $F$ & Prob $>F$ \\
\hline Model Effc $i t$ & 8 & 74.2900002 & 9.28625002 & 7.40 & 0.0000 \\
Residuals & 994 & 227.230502 & 1.25541714 & - & - \\
Total & 1,002 & 301.520503 & 1.59534657 & - & -
\end{tabular}

Source(s): https://drive.google.com/file/d/1EAolqaSq069gmyItAaombSFxEraziqLb/view

Table 11.

ANOVA test of the CBs' efficiencies

\begin{tabular}{lccccc}
\hline Source & Degree of freedom & Sum of squares & Average squares & $F$ & $\begin{array}{c}\text { Sig } \\
\text { Prob }>F\end{array}$ \\
\hline Model Effi $i t$ & 8 & 0.044575637 & 0.005571955 & 4.38 & 0.0001 \\
Residuals & 999 & 0.234211487 & 0.001272889 & - & - \\
Total & 1,007 & 0.278787124 & 0.001452016 & - & -
\end{tabular}

Note(s): $N=2,224$ and $k=9$

$\mathrm{Fe} \rightarrow(9 ; 2,206)$

$\mathrm{Fce}=\frac{\mathrm{RSS}-(\mathrm{RSS} 1+\mathrm{RSS} 2)}{\mathrm{RSS} 1+\mathrm{RSS} 2} * \frac{N-2 k}{k}=\frac{402.399-(227.230+0.234)}{(227.230+0.234)} * \frac{2224-(2 * 9)}{9}=188.506>1.59$

where Fce $=F$ calculated of the efficiency

Source(s): https://drive.google.com/file/d/1EAolqaSq069gmyItAaombSFxEraziqLb/view

Table 12 .

ANOVA test of the IBs efficiencies

\begin{tabular}{lccccc}
\hline & & & \multicolumn{2}{c}{ Sig } \\
Source & Degree of freedom & Sum of squares & Average squares & $F$ & Prob $>F$ \\
\hline Model Liq & 8 & 1.83051405 & 0.228814256 & 6.22 & 0.0000 \\
Residuals & 1,997 & 14.9053291 & 0.036803282 & - & - \\
Total & 2,005 & 16.7358431 & 0.040522623 & - & -
\end{tabular}

Source(s): https://drive.google.com/file/d/1a1IDaPiTPwIOERaTqZzAtyaBz7MDzShH/view

Table 13.

ANOVA test of the overall sample liquidity 
AJAR

7,3

240

Table 14

ANOVA test of the CBs' liquidities
3.2.4 Model of the AC effects on the banks' solvency. The solvency model variances revealed that the CFS was weaker than the tabulated statistics. That is why we immediately rejected the stability hypothesis for these models. Therefore, we concluded that the AC coefficients relating to the solvency-specific models of the conventional and Islamic banks were not stable.

\section{Empirical results}

To value the impact of ACQ on the FP in each bank type, it was necessary to estimate the partial impacts provided by each $\mathrm{AC}$ variable in each model. To complete this work, we compared similar partial impacts across multiple linear models. Since the effects resulting from the models could be insignificant, positive or negative, we insisted only on the

\begin{tabular}{lccccc}
\hline Source & Degree of freedom & Sum of squares & Average squares & $F$ & $\begin{array}{c}\text { Sig } \\
\text { Prob }>F\end{array}$ \\
\hline Model Liqc $i t$ & 8 & 1.15631667 & 0.144539584 & 5.18 & 0.0000 \\
Residuals & 888 & 5.9120502 & 0.027887029 & - & - \\
Total & 996 & 7.06836687 & 0.03212894 & - & -
\end{tabular}

Source(s): https://drive.google.com/file/d/1a1IDaPiTPwIOERaTqZzAtyaBz7MDzShH/view
Table 15.

ANOVA test on the IBs' liquidities

\begin{tabular}{|c|c|c|c|c|c|}
\hline Source & Degree of freedom & Sum of squares & Average squares & $F$ & $\begin{array}{c}\text { Sig } \\
\text { Prob }>F\end{array}$ \\
\hline Model Liqi $i_{i t}$ & 8 & 1.54503819 & 0.193129773 & 4.63 & 0.0000 \\
\hline Residuals & 998 & 7.68004327 & 0.041739366 & - & - \\
\hline Total & 1,006 & 9.22508146 & 0.048047299 & - & - \\
\hline \multicolumn{6}{|c|}{$\begin{array}{l}\text { Note(s): } N=2,224 \text { and } k=9 \\
\mathrm{Fl} \rightarrow(9 ; 2,206) \\
\mathrm{Fcl}=\frac{\mathrm{RSS}-(\mathrm{RSS} 1+\mathrm{RSS} 2)}{\mathrm{RSS} 1+\mathrm{RSS} 2} * \frac{N-2 k}{k}=\frac{14.905-(5.912+7.680)}{(5.912+7.680)} * \frac{2224-(2 * 9)}{9}=23.677>1.59 \\
\text { where } \mathrm{Fcl}=F \text { calculated of the liquidity } \\
\text { Source(s): https://drive.google.com/file/d/1a1IDaPiTPwIOERaTqZzAtyaBz7MDzShH/view }\end{array}$} \\
\hline
\end{tabular}

Table 16.

ANOVA test of the overall sample solvency

\begin{tabular}{|c|c|c|c|c|c|}
\hline Source & Degree of freedom & Sum of squares & Average squares & $F$ & $\begin{array}{c}\text { Sig } \\
\text { Prob }>F\end{array}$ \\
\hline Model LnSol $i t$ & 8 & 275.527625 & 14.501454 & 2.08 & 0.0365 \\
\hline Residuals & 1,991 & 1034.58404 & 2.8979945 & - & - \\
\hline Total & 1,999 & 1310.11166 & 3.48433953 & - & - \\
\hline
\end{tabular}

Source(s): https://drive.google.com/file/d/1nViRb5sSSPCXLVUcw2dECtzqTfqGajri/view

\begin{tabular}{lccccc}
\hline Source & Degree of freedom & Sum of squares & Average squares & $F$ & $\begin{array}{c}\text { Sig } \\
\text { Prob }>F\end{array}$ \\
\hline Model LnSolc $i t$ & 8 & 6.97821471 & 0.872276839 & 3.15 & 0.0022 \\
Residuals & 996 & 58.7799263 & 0.277263803 & - & - \\
Total & 1,004 & 65.7581411 & 0.298900641 & - & -
\end{tabular}

Table 17.

ANOVA test of the CBs' solvencies

Source(s): https://drive.google.com/file/d/1nViRb5sSSPCXLVUcw2dECtzqTfqGajri/view 
significant variables which explained the impacts' quality in each model and consequently the quality of the AC's determinants. In what follows, Tables 19-26 illustrate the different effects of different AC's determinants on the different FP measures for each bank type.

\subsection{Interpretation of the comparative results of the AC determinants' impacts on the FP} measures of the conventional and Islamic banks

4.1.1 Impacts of the ACQ on the profitability of conventional and Islamic banks. The results of the correlation between the CBs' profitabilities and the auditing system were most statistically significant. Table 19 illustrates the parameters of the effects between the

\begin{tabular}{lccccc}
\hline & & & \multicolumn{2}{c}{ Sig } \\
Source & Degree of freedom & Sum of squares & Average squares & $F$ & Prob $>F$ \\
\hline Model LnSoli $i t$ & 8 & 110.672255 & 13.8340318 & 2.25 & 0.0258 \\
Residuals & 992 & 1132.02882 & 6.15233055 & - & - \\
Total & 1,000 & 1242.70108 & 6.47240144 & - & -
\end{tabular}

Note(s): $N=2,224$ and $k=9$

$\mathrm{Fs} \rightarrow(9 ; 2,206)$

$\mathrm{FCS}=\frac{\mathrm{RSS}-(\mathrm{RSS} 1+\mathrm{RSS} 2)}{\mathrm{RSS} 1+\mathrm{RSS} 2} * \frac{N-2 k}{k}=\frac{1034.584-(58.779+1132.028)}{(58.779+1132.028)} * \frac{2224-(2 * 9)}{9}=-32.156<1.59$

where $\mathrm{Fcs}=F$ calculated of the solvency

Source(s): https://drive.google.com/file/d/1nViRb5sSSPCXLVUcw2dECtzqTfqGajri/view
The effect of audit committee quality

\begin{tabular}{lrlrlrr}
\hline LnProc & Coefficient & Std. err & $Z$ & $P>|z|$ & \multicolumn{1}{c}{ [95\% Conf. interval] } \\
\hline LnTCOMc & -0.3690006 & 0.3122912 & -1.18 & $0.019^{* *}$ & -0.9850671 & 0.2470659 \\
LnPRESEXPc & 0.3256752 & 0.1707604 & 1.91 & $0.058^{*}$ & -0.0111891 & 0.6625395 \\
LnINDCOMc & -0.2007704 & 0.1353857 & -1.48 & $0.014^{* *}$ & -0.46785 & 0.0663092 \\
LnREUCOMc & -0.7691618 & 0.1381292 & -5.57 & $0.000^{* * *}$ & -1.041653 & -0.4966701 \\
TYc & -0.0459267 & 0.1075946 & -0.43 & 0.670 & -0.1663286 & 0.258182 \\
LnAGc & 0.2706567 & 0.1054468 & 2.57 & $0.001^{* * *}$ & 0.0626385 & 0.4786749 \\
LnTAc & 0.1641456 & 0.2123066 & 0.77 & $0.023^{* *}$ & -0.2546783 & 0.5829695 \\
LnINFc & -0.310217 & 0.1021077 & -3.04 & $0.003^{* * *}$ & -0.5116481 & -0.1087859 \\
Constant & 3.930467 & 0.7296175 & 5.39 & 0.000 & 2.491128 & 5.369806
\end{tabular}

Note(s): * Correlation is significant at the 0.10 level; ** Correlation is significant at the 0.05 level; **** Correlation is significant at the 0.01 level

Source(s): https://drive.google.com/file/d/1zr0D_kdjO3advHF23hSyj15EeNOiY2TY/view

Table 18.

ANOVA Test of the IBs' solvencies

\begin{tabular}{lccrlrr}
\hline LnProi & Coefficient & Std. err & $Z$ & $P>|z|$ & \multicolumn{1}{c}{ [95\% Conf. interval] } \\
\hline LnTCOMc & 0.7456123 & 0.3303697 & 2.26 & $0.025^{* * *}$ & 0.0930042 & 1.39822 \\
LnPRESEXPc & -0.1899257 & 0.1819712 & -1.04 & $0.006^{* * *}$ & -0.5493892 & 0.1695378 \\
LnINDCOMc & -0.3311608 & 0.1371441 & -2.41 & $0.017^{* *}$ & -0.6020736 & -0.0602481 \\
LnREUCOMc & -0.0635436 & 0.1378169 & -0.46 & 0.645 & -0.3357853 & 0.2086981 \\
TYc & 0.2751691 & 0.1047932 & 2.63 & $0.010^{* * *}$ & 0.0681619 & 0.4821763 \\
LnAGc & 0.1788393 & 0.0933347 & 1.92 & $0.000^{* * *}$ & -0.0055329 & 0.3632115 \\
LnTAc & -0.7546426 & 0.3303035 & -2.28 & $0.024^{* *}$ & -1.40712 & -0.1021653 \\
LnINFc & -0.6660688 & 0.1191256 & -5.59 & $0.000^{* * *}$ & -0.9013879 & -0.4307496 \\
Constant & 3.865778 & 0.7613688 & 5.08 & 0.000 & 2.36178 & 5.369776
\end{tabular}

Note(s): ** Correlation is significant at the 0.05 level; *** Correlation is significant at the 0.01 level

Source(s): https://drive.google.com/file/d/190xC-_q6vxJ1oPSoEHwXdq8JCQeUXkVs/view

Table 19. Regression results of the AC's impacts on the CBs' profitability 


\section{AJAR 7,3}

242

Table 21.

Regression results of the AC's impacts on the CBs' efficiency

\begin{tabular}{lccrccc}
\hline Effc & Coefficient & Std. err & \multicolumn{1}{c}{$Z$} & $P>|z|$ & \multicolumn{2}{c}{$[95 \%$ Conf. interval] } \\
\hline LnTCOMc & 0.5635711 & 0.3854691 & 1.46 & $0.095^{*}$ & -0.1970199 & 1.324162 \\
LnPRESEXPc & -0.506293 & 0.2114613 & -2.39 & $0.018^{* *}$ & -0.9235392 & -0.0890467 \\
LnINDCOMc & -0.3365649 & 0.1692185 & -1.99 & $0.048^{* *}$ & -0.6704596 & -0.0026701 \\
LnREUCOMc & -0.2915094 & 0.1725128 & -1.69 & $0.003^{* * *}$ & -0.6319043 & 0.0488855 \\
TYc & 0.0216742 & 0.1403389 & 0.15 & 0.877 & -0.2985849 & 0.2552366 \\
LnAGc & 0.3503843 & 0.132294 & 2.65 & $0.009^{* * *}$ & 0.0893475 & 0.611421 \\
LnTAc & -0.7260411 & 0.2902967 & -2.50 & $0.013^{* *}$ & -1.298842 & -0.1532401 \\
LnINFc & 0.4523007 & 0.1265786 & 3.57 & $0.000^{* * *}$ & 0.2025413 & 0.7020601 \\
Constant & -3.639358 & 0.9526918 & -3.82 & 0.000 & -5.519168 & -1.759547
\end{tabular}

Note(s): * Correlation is significant at the 0.10 level; ** Correlation is significant at the 0.05 level; **** Correlation is significant at the 0.01 level

Source(s): https://drive.google.com/file/d/1YOP2GsdZQ9dhSiH5DHc7mkBIqah0BeGi/view
Table 22.

Regression results of the AC's impacts on the IBs' efficiency

\begin{tabular}{|c|c|c|c|c|c|c|}
\hline Effi & Coefficient & Std. err & $Z$ & $P>|z|$ & \multicolumn{2}{|c|}{ [95\% Conf. interval] } \\
\hline LnTCOMi & -0.5635711 & 0.3854691 & -1.46 & $0.002 * * *$ & -0.1970199 & 1.324162 \\
\hline LnPRESEXPi & 0.506293 & 0.2114613 & 2.39 & $0.018^{* *}$ & -0.9235392 & -0.0890467 \\
\hline LnINDCOMi & -0.3365649 & 0.1692185 & -1.99 & $0.048 * *$ & -0.6704596 & -0.0026701 \\
\hline LnREUCOMi & 0.2915094 & 0.1725128 & 1.69 & $0.093^{*}$ & -0.6319043 & 0.0488855 \\
\hline TYi & 0.0216742 & 0.1403389 & 0.15 & $0.055^{*}$ & -0.2985849 & 0.2552366 \\
\hline LnAGi & 0.3503843 & 0.132294 & 2.65 & $0.009 * * * *$ & 0.0893475 & 0.611421 \\
\hline LnTAi & 0.7260411 & 0.2902967 & 2.50 & $0.013 * *$ & -1.298842 & -0.1532401 \\
\hline LnINFi & 0.4523007 & 0.1265786 & 3.57 & $0.000 * * *$ & 0.2025413 & 0.7020601 \\
\hline Constant & -3.639358 & 0.9526918 & -3.82 & 0.000 & -5.519168 & -1.759547 \\
\hline
\end{tabular}

Note(s): * Correlation is significant at the 0.10 level; ** Correlation is significant at the 0.05 level; *** Correlation is significant at the 0.01 level

Source(s): https://drive.google.com/file/d/1uQo-U_mQhEfbbdfLJiOGEK1ixGt6MgsJ/view

\begin{tabular}{lrlrlrr}
\hline Liqc & Coefficient & \multicolumn{1}{c}{ Std. err } & \multicolumn{1}{c}{$Z$} & $P>|z|$ & \multicolumn{2}{c}{$[95 \%$ Conf. Interval] } \\
\hline LnTCOMc & 0.0230827 & 0.0132145 & 1.75 & $0.064^{*}$ & -0.0491541 & 0.0029887 \\
LnPRESEXPc & -0.0027156 & 0.0068792 & -0.39 & 0.693 & -0.0108566 & 0.0162878 \\
LnINDCOMc & -0.0001795 & 0.005707 & -0.03 & 0.975 & -0.01108 & 0.0114391 \\
LnREUCOMc & 0.0053715 & 0.0058016 & 0.93 & $0.006^{* * *}$ & -0.0060748 & 0.0168178 \\
TYc & -0.0001909 & 0.004128 & -0.05 & 0.963 & -0.0083351 & 0.0079534 \\
LnAGc & 0.0097612 & 0.0031573 & 3.09 & $0.002^{* * *}$ & 0.0035321 & 0.0159903 \\
LnTAc & -0.0276267 & 0.0112254 & -2.46 & $0.000^{* * *}$ & 0.0054796 & 0.0497737 \\
LnINFc & -0.0050449 & 0.0047604 & -1.06 & $0.001^{* * *}$ & -0.004347 & 0.0144368 \\
Constant & -0.0618575 & 0.0255779 & -2.42 & 0.017 & -0.1123213 & -0.0113938
\end{tabular}

Table 23.

Regression results of the AC's impacts on the CBs' liquidity
Note(s): * Correlation is significant at the 0.10 level; *** Correlation is significant at the 0.01 level Source(s): https://drive.google.com/file/d/1sFDe0s77tVI3rFXNV1UZaNLALsKZt1Pt/view

profitability and the set of variables subject to the test. Based on the table below, the AC coefficients revealed two conclusions. LnTCOMc, LnINDCOMc and LnREUCOMc negatively and significantly affected the CBs' profitability at the 5, 5 and $1 \%$ levels, respectively. Nonetheless, LnPRESEXPc reported a favorable and significant impact on the CBs' profitability at the $10 \%$ threshold. The results analysis for the control variables showed that LnINFc seriously affected the CBs' profitability at the $1 \%$ threshold, while LnAGc and 


\begin{tabular}{lrlrlrr}
\hline Liqi & Coefficient & Std. err & \multicolumn{1}{c}{$Z$} & $P>|z|$ & \multicolumn{2}{c}{$[95 \%$ Conf. interval] } \\
\hline LnTCOMi & -0.0103563 & 0.0536024 & -0.19 & 0.847 & -0.1160183 & 0.0953058 \\
LnPRESEXPi & 0.0355094 & 0.0292879 & 1.21 & 0.227 & -0.0222234 & 0.0932423 \\
LnINDCOMi & -0.0001826 & 0.0236885 & -0.01 & $0.001^{* * *}$ & -0.0465126 & 0.0468778 \\
LnREUCOMi & 0.0619193 & 0.0241388 & 2.57 & $0.000^{* * *}$ & 0.0143365 & 0.1095022 \\
TYi & -0.0198306 & 0.0184098 & -1.08 & 0.283 & -0.0561204 & 0.0164592 \\
LnAGi & 0.0271863 & 0.0180877 & 1.50 & $0.034^{* * *}$ & -0.0084685 & 0.0628411 \\
LnTAi & 0.0996069 & 0.034553 & 2.88 & $0.004^{* * *}$ & -0.1677184 & -0.0314955 \\
LnINFi & -0.0798724 & 0.0179172 & -4.46 & $0.000^{* * *}$ & -0.1151912 & -0.0445537 \\
Constant & 0.7640561 & 0.119199 & 6.41 & 0.000 & 0.5290891 & 0.9990231
\end{tabular}

Note(s): ** Correlation is significant at the 0.05 level; *** Correlation is significant at the 0.01 level

Source(s): https:/drive.google.com/file/d/14v7xK3pqWGi01XaS-6I1uBgAUHiz2mHG/view

The effect of audit committee quality

\section{3}

Table 24.

Regression results of the AC's impacts on the IBs' liquidity

\begin{tabular}{lccrlrr}
\hline LnSolc & Coefficient & Std. err & \multicolumn{1}{c}{$Z$} & $P>|z|$ & \multicolumn{1}{c}{ [95\% Conf. interval] } \\
\hline LnTCOMc & -0.0192461 & 0.0756708 & -0.25 & $0.002^{* * * *}$ & -0.130048 & 0.1685402 \\
LnPRESEXPc & 0.0017022 & 0.0393925 & 0.04 & $0.006^{* * * *}$ & -0.0760169 & 0.0794213 \\
LnINDCOMc & -0.0731493 & 0.0326802 & -2.24 & 0.226 & -0.1376254 & -0.0086733 \\
LnREUCOMc & 0.03582 & 0.0332222 & 1.08 & $0.000^{* * * *}$ & -0.0297254 & 0.1013653 \\
TYc & -0.0013657 & 0.0236383 & -0.06 & 0.954 & -0.0452713 & 0.0480027 \\
LnAGc & -0.005686 & 0.0180797 & -0.31 & 0.753 & -0.0299841 & 0.0413561 \\
LnTAc & -0.2723791 & 0.0642805 & -4.24 & $0.000^{* * *}$ & 0.1455574 & 0.3992008 \\
LnINFc & -0.0366407 & 0.0272595 & -1.34 & $0.001^{* * *}$ & -0.0904222 & 0.0171407 \\
Constant & -0.0203986 & 0.1464682 & -0.14 & 0.889 & -0.3093716 & 0.2685743
\end{tabular}

Note(s): *** Correlation is significant at the 0.01 level

Source(s): https://drive.google.com/file/d/1yjfd6XunbuRPYkqljyhjGMVQsYJTz-y8/view

Table 25.

Regression results of the AC's impacts on the CBs' solvency

\begin{tabular}{lccrlrr}
\hline LnSoli & Coefficient & Std. err & \multicolumn{1}{c}{$Z$} & $P>|z|$ & \multicolumn{2}{c}{$[95 \%$ Conf. interval] } \\
\hline LnTCOMi & 0.257406 & 0.1690168 & 1.52 & $0.009^{* * *}$ & -0.5905748 & 0.0757628 \\
LnPRESEXPi & -0.1461662 & 0.0923494 & 1.58 & $0.032^{* *}$ & -0.0358745 & 0.3282069 \\
LnINDCOMi & -0.0316474 & 0.0746935 & -0.42 & $0.017 * *$ & -0.1155897 & 0.1788846 \\
LnREUCOMi & -0.152596 & 0.0761134 & -2.00 & $0.056^{*}$ & 0.00256 & 0.3026321 \\
TYi & 0.138241 & 0.0580491 & 2.38 & $0.018^{* *}$ & -0.2526684 & -0.0238136 \\
LnAGi & -0.0182011 & 0.0570333 & -0.32 & 0.750 & -0.1306261 & 0.094224 \\
LnTAi & 0.0705174 & 0.108951 & 0.65 & 0.518 & -0.2852834 & 0.1442486 \\
LnINFi & -0.1730838 & 0.0564959 & -3.06 & $0.002^{* * *}$ & -0.2844495 & -0.0617182 \\
Constant & 0.5057693 & 0.3758529 & 1.35 & 0.180 & -0.2351183 & 1.246657
\end{tabular}

Note(s): * Correlation is significant at the 0.10 level ** Correlation is significant at the 0.05 level; **** Correlation is significant at the 0.01 level

Source(s): https:/drive.google.com/file/d/12aV5sGw9G8Jqn_cW9foCHr_hEOxKyLO_/view

Table 26. Regression results of the AC's impacts on the IBs' solvency

LnTAc positively influenced profitability at significant levels of 1 and 5\%, respectively. According to Table 19, assumptions H1 and H4 were confirmed. However, assumptions H2 and $\mathrm{H} 3$ were ignored.

According to Table 20, the correlation between the AC characteristics and the IBs' profitabilities indicated that most coefficients of this model were statistically significant. We found that there were only two $\mathrm{AC}$ determinants that had important significance at the $5 \%$ level. LnTCOMi revealed a positive effect on profitability, while LnINDCOMi negatively 
AJAR 7,3 affected it. However, LnPRESEXPi negatively and significantly impacted the IBs' profitability at the $1 \%$ threshold. The other $\mathrm{AC}$ characteristic showed a negative and insignificant effect. In terms of the auxiliary variables, LnTAi and LnINFi negatively and significantly affected the IBs' profitabilities at the 5 and $1 \%$ levels, respectively. Nevertheless, TYi and LnAGi adopted positive and significant signs on profitability at the threshold of $1 \%$. From the deliberate conclusions, we accepted only the second hypothesis. On the contrary, Hypotheses 1, 3, and 4 were rejected.

4.1.2 Impacts of the ACQ on the efficiency of conventional and Islamic banks. According to Table 21, the specific model of the CB efficiency proved the presence of some statistically significant variables in the exhaustive list of the variables. Dealing with the effect of dependence between the AC's determinants and the $\mathrm{CB}$ efficiency concluded that three $\mathrm{AC}$ determinants that generated significant and negative impacts on the effectiveness of the CBs' ACs at the 5\% level (LnPRESEXPc and LnINDCOMc), and at the 1\% level (LnREUCOMc). On the contrary, we recorded that LnTCOMc revealed a positive impact on the efficacy at the level of $10 \%$. The empirical results also showed that TYc, LnAGc and, LnINFc generated a positive sign, notwithstanding these impacts, and only those that corresponded to LnAGc and LnINFc were significant at the $1 \%$ threshold. While LnTAc reported a negative impact on the CBs' efficiencies, it reaches the level of $5 \%$ significance. Consequently, Hypotheses 2 and 4 were accepted, but Hypotheses 1 and 3 were rejected.

Referring to Table 22, this model supported some influential variables in valuing the ACQ in relation to IB efficiency. It revealed that all variables were significant. Similarly, the results specific to the impact of the AC determinants on the IB effectiveness showed that LnTCOMi and LnINDCOMi negatively and significantly affected the IB efficiency at the respective rates of 1 and $5 \%$, whereas the other determinants positively and significantly influenced the IB efficiency. The impact of the LnPRESEXPi was significant at the level of 5\%; however, LnREUCOMi was significant at the level of $10 \%$. Regarding the control variables, all of them had a positive impact on the IB efficiency. Among these variables, the LnAGi and LnINFi had significant and influential effects at the $1 \%$ threshold, and LnTAi was significant at the $5 \%$ threshold, while TYi was significant at the $10 \%$ threshold. This illustration convinced us to validate Hypothesis 1 in the IB framework, while Hypotheses 2, 3 and 4 are rejected.

4.1.3 Impacts of the ACQ on the liquidity of conventional and Islamic banks. Table 23 includes the results of the $\mathrm{CB}$ liquidity model. The provided coefficients indicated that only a few variables were statistically significant. The results underlined that this model was the least significant in the set of estimated regressions. The analysis showed that LnPRESEXPc and LnINDCOMc had negatively affected the $\mathrm{CB}$ liquidity, but these effects were insignificant. Nonetheless, LnTCOMc and LnREUCOMc played a fundamental role in forcing the liquidity production cycle at the levels of 10 and $1 \%$, respectively. Focusing on the impacts of the control variables on liquidity, we found that TYc, LnTAc and LnINFc negatively affected the cash flow, though not necessarily significantly, except that the impacts received by LnTAc and LnINFc were significant at the $1 \%$ level. However, LnAGc's liquidity strength was positive and significant at the $1 \%$ rate. This is why we ignored all our hypotheses.

As shown in Table 24, the attributes of the IB liquidity model revealed that it was of globally fair quality, since there were only a few variables that were statistically significant. The liquidity model gave rise to coefficients with positive signs just like LnPRESEXPi and LnREUCOMi, but only LnREUCOMi was significant at the rate of $1 \%$. Nonetheless, the effects on LnTCOMi and LnINDCOMi were negative, but only LnINDCOMi effectively affected the IB liquidity at the $1 \%$ level. Regarding the effects of the additional variables on the IB liquidity, the combinatorial effect generated by LnAGi and LnTAi was a stimulator for the IB liquidity, even though LnAGi showed a significant impact at the level of $5 \%$, while LnTAi recorded a significant impact at the level of $1 \%$. However, TYi and LnINFi negatively 
affected the IB liquidity. By way of exception, only LnINFi deteriorated the available liquidity pool at a rate of $1 \%$. For this reason, we validated the first hypothesis in the case of IBs. After all, Hypotheses 2, 3 and 4 were rejected.

4.1.4 Impacts of the ACQ on the solvency of conventional and Islamic banks. The results of the estimated model of $\mathrm{CB}$ solvency showed that most of the impacts were statistically significant. This model was considered among the most significant models that remained. In the following, based on Table 25, the signs of an AC's determinants revealed that LnPRESEXPc and LnREUCOMc improved the CB solvency ratio at the level of significance of $1 \%$. On the contrary, LnTCOMc and LnINDCOMc lowered the CB solvency, but only LnTCOMc was extremely significant at the $1 \%$ level. The results revealed that all other control variables showed a worrisome impact on the continued $\mathrm{CB}$ solvency, but only the relative impacts of LnTAc and LnINFc were significant at the $1 \%$ threshold. As a result, we confirmed only Hypothesis 1 in the context of CBs, but we explicitly rejected Hypotheses 2, 3 and 4 .

The results of the IB solvency model revealed that there was an average number of variables whose impacts were statistically significant. Table 26 illustrates that three AC determinants exerted pressure to deteriorate the IB solvency, such as LnPRESEXPi, LnINDCOMi, and LnREUCOMi. Nonetheless, the effects related to LnPRESEXPi and LnINDCOMi were significant at the 5\% level, but the LnREUCOMi impact was significant just at the level of $10 \%$, whereas, LnTCOMi protected the IB solvency significantly at the $1 \%$ threshold. Symmetrically, we appreciated that TYi and LnTAi informed us about their favorable effects on solvency, but also, we indicated that only the impact of TYi was significant at the limit of 5\%. However, we reported that LnAGi and LnINFi recorded prodigious negative effects, but only inflation reported a significant impact on solvency at the $1 \%$ level. These results allowed us to validate Hypotheses 2 and 4 . On the contrary, assumptions $\mathrm{H} 1$ and $\mathrm{H} 3$ are rejected.

Before concluding, it is important to note that the mono-analysis showed confusion for confirming or infirming our hypotheses from a single FP measure. Furthermore, not all tested variables revealed significant impacts on FP measures. The existence of the various signs allowed us to think differently about a new AC model, allowing us to overcome the problem of signs ambiguity, give us standard effects for each bank type, eliminate the signs' diversity, and constitute an effective and feasible solution to implement it whatever the bank type.

\subsection{Analogical study between the significant impacts of the ACQ on the FP measures}

Based on the above, we retained that whatever the FP measure, the significant impacts of the AC's determinants were not identical between measures of the same bank type and between equivalent models' effects for each bank type, and not all the $\mathrm{AC}$ determinants revealed significant impacts on FP measures for each bank type. Thus, it is impossible to compare the incomparable. To overcome the constraints of mono-analysis which prevented us from making a final decision on the assumptions due to the diversity of impacts from each determinant on each FP measure, we created a new method called the Decisive Choice Method "MCD" to make a final comparative decision. Moreover, this method made it easier for us to choose the right ACQ and the right bank model through FP. To exceed the diversity of individual effects, we counted only the variables revealing significant impacts. Table 27 shows the ranking of the significant effects of two bank types according to their signs:

As illustrated in Table 27, before comparing the similar impacts, this method consisted of ruling out the insignificant impacts and considered only the significant impacts at the limit of $10 \%$. Then we classified the common determinants of ACs that revealed significant impacts according to the signs between the two bank types. Based on the main results, bringing all the AC impacts on FP together showed that the ACQ in both bank types weakened a part of their
The effect of audit committee quality 


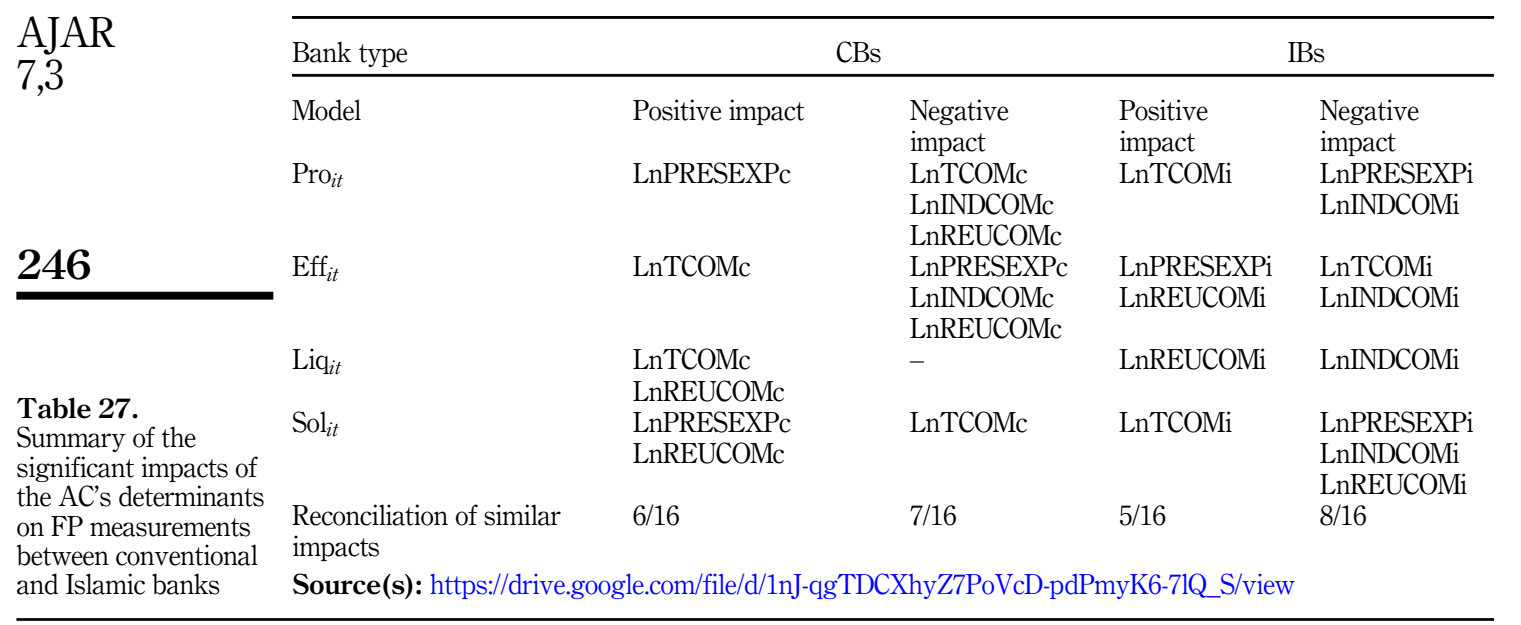

profitability, their efficiency, their liquidity, and their solvency, although their ACs protected some part of the same FP measures. However, the number of positive impacts of the ACs on the different CB FP measures was greater than those relating to the IBs. Furthermore, the ACs' negative impacts corresponding to the CBs' $\mathrm{FP}$ measures were lower than those relating to IBs. Therefore, we concluded that the CBs better governed their FP thanks to the AC more than their Islamic counterparts. Within the IBs, this result was explained by the decline in the importance of this governance mechanism in favor of other mechanisms, such as the Charia committee and its weaknesses, in ensuring their role in monitoring FP. Unlike IBs, within the $\mathrm{CBs}$, the negative impacts outweighed the positive impacts. This indicates the failure of this mechanism to overhaul, manage, and perfect the CBs' FPs. According to the literature, we did not find any comparative studies that exactly studied the AC's impact on the FPs of two bank types. In contrast, Salem et al. (2021) examined the impact of ACs on earnings management through loan loss provisions among both conventional and Islamic banks operating in MENA countries. They found that the $\mathrm{AC}$ size and independence restrained the earnings management practices of IBs' managers more than those of CBs' managers.

\section{Conclusion}

Based on an analysis of partial effects, our study showed that whatever the bank type, it was not obvious that listed banks which controlled their ACs' compositions would necessarily improve their FPs. Moreover, our results indicated that large banks were neither exempted nor protected against practices of diversion and methods of devaluing FP, whether by acting on its measures or by playing on the ACs' determinants. Although within conventional and Islamic banks everything is proportional, the presence of inadequacies in the governance systems of this bank category always causes variability in their FPs. Furthermore, the volume and complexity of listed bank transactions require a shift in vision toward the role and location of ACs. From our results, we discovered that the real role of ACs was to bear an additional responsibility for improving $\mathrm{FP}$, not only as a governance and control mechanism but also as a continuous monitoring mechanism of the whole process of creation of the FP. By giving an additional task integrated into the ACs' accounts, they will become more responsible to bear the challenges of the ACs' weaknesses (Nkegbe and Ustarz, 2015; Saani, 2017). 
From the outputs of our study and, more precisely, based on the percentage of positive and negative impacts, we noticed that the IBs' ACs contributed more to the improvement of their FPs compared with the CBs. However, in the two bank types, the number of determinants which have negatively influenced $\mathrm{FP}$ is very close to that of determinants which have recorded positive impacts. The negative impacts can be explained in proportion to the bank type. Implicitly, the percentage of non-significant partial impacts in each bank type is equal to $18.75 \%$ of the total number of impacts from ACs on all FP measures. The presence of non-significant partial impacts on the banking FP provides the failure of these determinants or mechanisms staging their roles in an effective behavioral attitude, especially those which are directly associated with decision centers. Regardless of the bank type, an $\mathrm{AC}$ is responsible for planning policies and making the best decisions. It is required to improve the FP and maximize the bank's profits. However, the lack of FP affects the credibility and feasibility of implementing a quality governance system. This embodies two conclusions: there are many substitutable mechanisms behind the ambiguous effect, and there is a complete failure of the actual governance system that requires a revision.

Like all research studies, there are a few limitations to note. First, we compared only the ACs' effects of conventional and Islamic banks. In future research, we may broaden the scope of our study through the integration of other types of conventional and Islamic financial institutions so that it is possible to generalize the results to related financial sectors. Indeed, this study only dealt with the impact of a few ACs' determinants on a few FP measures. As a new research perspective, future studies could test the impact of several other determinants on a more exhaustive list of FP measures.

\section{Notes}

1. Chief Executive Officer.

2. https://drive.google.com/file/d/1_8Nz6t-uki1ucY9qsyc740d75QAV1KAz/view.

\section{References}

Abbott, L.J., Parker, S. and Peters, G.F. (2004), “Audit committee characteristics and restatements", Journal of Practice and Theory, Vol. 23 No. 1, pp. 69-87.

Alzoubi, E. and Selamat, M. (2012), "The effectiveness of corporate governance mechanisms on constraining earning management: literature review and proposed framework", International Journal of Global Business, Vol. 5 No. 1, pp. 17-35.

Aminul, A., Niki, L., Djoko, S. and Erna, S. (2018), "Audit committee characteristics and auditearnings quality: empirical evidence of the company with concentrated ownership", Review of Integrative Business and Economics Research, Vol. 7 No. 1, pp. 18-33.

Anderson, R.C., Mansi, S.A. and Reeb, D.M. (2004), "Board characteristics, accounting report integrity and cost of debt", Journal of Accounting and Economics, Vol. 37 No. 3, pp. 315-342.

Arif, H., Khalil, Y.K. and Bilal, M. (2017), "Risk taking behavior of commercial banks in Pakistan”, City University Research Journal, Vol. 7 No. 2, pp. 317-333.

Ashari, S. and Krismiaji, K. (2020), "Audit committee characteristics and financial performance: Indonesian evidence”, Equity, Vol. 22 No. 2, pp. 139-152.

Assenga, M.P., Aly, D. and Hussainey, K. (2018), "The impact of board characteristics on the financial performance of Tanzanian firms", Corporate Governance: The International Journal of Business in Society, Vol. 18 No. 6, pp. 1089-1106.

Awinbugri, A.E. and Prince, G. (2019), "The impact of audit committees' meetings and audit fees on the financial performance of listed banks in Ghana", International Journal of Research and Innovation in Social Science, Vol. 3 No. 5, pp. 341-346.
The effect of audit committee quality 
AJAR

7,3

Baiden, J.N.E. (2020), "Board audit committee characteristics and financial performance of selected commercial banks in Ghana", International Journal of Accounting and Financial Reporting, Vol. 1 No. 1, pp. 222-232.

Beasley, M.S. (1996), "An empirical analysis of the relation between the board of director composition and financial statement fraud”, The Accounting Review, Vol. 71 No. 4, pp. 443-465.

Beasley, M.S., Carcello, J.V., Hermanson, D.R. and Neal, T.L. (2009), "The audit committee oversight process", Contemporary Accounting Research, Vol. 26 No. 1, pp. 65-122.

Bilal, Chen, S. and Komal, B. (2018), "Audit committee financial expertise and earnings quality: a meta-analysis", Journal of Business Research, Vol. 84 No. C, pp. 253-270.

Bouaine, W. and Hrichi, Y. (2019), "Impact of audit committee adoption and its characteristics on financial performance: evidence from 100 French companies", Accounting and Finance Research, Vol. 8 No. 1, p. 92.

Bouton, D. (2002), "For a better government of listed companies", Report of the working group chaired by Daniel Bouton, AFEP, AGREF, MEDE, p. 33.

Bryan, D., Liu, M.H. and Tiras, S.L. (2004), "The influence of independent and effective audit committees on earnings quality", Work document.

Carrera, N., Sohail, T. and Carmona, S. (2017), “Audit committees' social capital and financial reporting quality”, Accounting and Business Research, Vol. 47 No. 5, pp. 1-40.

Chaudhry, G. (2013), "Audit committees and financial reporting quality", $P h D$ Thesis, University of Sheffield.

Chen, J., Duh, R.R., Hsu, A.W.H. and Pan, C.M. (2015), "Can Anglo-Saxon audit committee scheme improve earnings quality in non- Anglo-Saxon environments?", Journal of Contemporary Accounting and Economics, Vol. 11 No. 1, pp. 61-74.

Chow, G.C. (1960), "Tests of equality between sets of coefficients in two linear regressions", Econometrica, Vol. 28 No. 3, pp. 591-605.

Collier, P. and Gregory, A. (1999), "Audit committee activity and the agency costs", Journal of Accounting and Public Policy, Vol. 18 Nos 4-5, pp. 311-332.

Cornett, M.M., McNutt, J.J. and Tehranian, H. (2009), "Corporate governance and earnings management at large US bank holding companies", Journal of Corporate Finance, Vol. 15 No. 4, pp. 412-430.

Darmadi, S. (2013b), "Corporate governance disclosure in the annual report: an exploratory study on Indonesian Islamic banks", Humanomics, Vol. 29 No. 1, pp. 4-23.

Deloitte (2007), "Promoting audit quality", Deloitte Touche Tohmatsu, available at: https://www.frc. org.uk/getattachment/8f9c7425-e898-4749-b255-3f9ca93e6865/Feedback-Paper-PromotingAudit-Quality-Oct-2007.pdf.

Dinu, V. and Nedelcu (Bunea), M. (2015), "The relationship between the audit committee and the financial performance, the asset quality and the solvency of banks in Romania", Transformations in Business and Economics, Vol. 14 No. 2 (35), pp. 161-173.

Elsiefy, E. (2013), “Comparative analysis of Qatari Islamic banks performance versus conventional banks before, during and after the financial crisis", International Journal of Business and Commerce, Vol. 3 No. 3, pp. 11-41.

Emilia, G.A. and Judit, M.C. (2012), "Firms as liquidity providers: evidence from the 2007-2008 financial crisis", Journal of Financial Economics, available at SSRN: https://ssrn.com/ abstract $=2023583$.

Gendron, Y. and Bedard, J. (2006), "On the constitution of audit committee effectiveness", Accounting, Organizations and Society, Vol. 31 No. 3, pp. 211-239.

Gul, F.A. (1989), "Bankers' perceptions of factors affecting auditor independence", Accounting, Auditing and Accountability Journal, Vol. 2 No. 3, pp. 40-51. 
Himaj, S. (2014), "Corporate governance in banks and its impact on risk and performance: review of literature on the selected governance mechanisms", Journal of Central Banking Theory and Practice, Vol. 3, pp. 53-85.

Indrawan, V., Agoes, S., Pangaribuan, H. and Popoola, O.M.J. (2018), "The impact of audit committee, firm size, profitability, and leverage on income smoothing", Indian-Pacific Journal of Accounting and Finance, Vol. 2 No. 1, pp. 61-74.

Krishnan, J. (2005), "Audit committee quality and internal control: an empirical analysis", The Accounting Review, Vol. 80 No. 2, pp. 649-675.

Krishnan, J. and Lee, J.E. (2009), "Audit committee financial expertise, litigation risk and corporate governance", A Journal of Practice and Theory, Vol. 28 No. 1, pp. 241-261.

Mangena, M. and Tauringana, V. (2007), "Disclousure, corporate governance and foreign share ownership on Zimbabwe stock exchange", Journal of International Financial Management and Accounting, Vol. 18 No. 2, pp. 53-85.

Moses, T., Ofurm, C. and Egbe, D.S. (2016), "Audit committee characteristics and quality of financial reporting in quoted Nigerian banks", International Journal of Advanced Academic Research, Vol. 2 No. 5, pp. 1-10.

Nahar, S. and Sarker, N. (2016), "Are macroeconomic factors substantially influential for Islamic bank financing? cross-country evidence", IOSR Journal of Business and Management, Vol. 18 No. 6 , pp. 20-27.

Nkegbe, P.K. and Ustarz, Y. (2015), "Banks performance in Ghana: trends and determinants", Ghana Journal of Development Studies, Vol. 12 Nos 1/2, pp. 33-52.

Norhidayah, A.K., Abdullah, N.R., Harun, N., Nordin, N.A. and Jaffar, A. (2011), "Financial performance of Islamic bank in Malaysia during and after economic crisis", Colloquium on Humanities, Science and Engineering Research Penang, IEEE, pp. 839-844.

Ogbeide, S. and Akanji, B. (2018), “A comparative assessment of the financial performance between religious-based and conventional banks in Nigeria", International Journal of Management Applications, Vol. 1 No. 1, pp. 1-7.

Poretti, C., Schatt, A. and Bruynseels, L. (2018), "Audit committees' independence and the information content of earning announcements in Western Europe", Journal of Accounting Literature, Vol. 40, pp. 29-53.

Rashid, A., Hassan, M.K. and Shah, M.A.R. (2020), "On the role of Islamic and conventional banks in the monetary policy transmission in Malaysia: do size and liquidity matter?", Research in International Business and Finance, Vol. 52, pp. 1-32.

Saad, S.S.M., Evans, J.G., Sori, Z.M. and Hamid, M.A. (2007), "Audit committee authority and effectiveness: the perceptions of Malaysian senior managers", International Research Journal of Finance and Economics, Vol. 8, pp. 41-56.

Saani, A.-J. (2017), "Influence of internal control systems on the general performance of microfinance institutions in Ashaiman Municipality", IUG Journal of Humanities and Social Sciences, Vol. 2 No. 1, pp. 114-131.

Salem, R., Usmana, M. and Ezeanib, E. (2021), "Loan loss provisions and audit quality: evidence from MENA Islamic and conventional banks", The Quarterly Review of Economics and Finance, Vol. 79 No. 1, pp. 345-359.

Sarbanes-Oxley Act (2002), Final Rule: Disclosure Required by Sections 406 and 407 of the SarbanesOxley Act of 2002, Securities and Exchange Commission, Washington.

Sattar, U., Javeed, S.A. and Latief, R. (2020), "How audit quality affects the firm performance with the moderating role of the product market competition: empirical evidence from Pakistani manufacturing firms", Sustainability, Vol. 12 No. 10, pp. 41-53.

Shahkaraiah, K. and Amiri, S.M. (2017), "Audit committee quality and financial reporting quality: a study of selected Indian companies", Journal of Accounting and Business, Vol. 4 No. 1, pp. 1-18.

The effect of audit committee quality 
AJAR 7,3

Tanyi, P.N. and Smith, B.D. (2015), "Busyness, expertise, and financial reporting quality of audit committee chairs and financial experts", A Journal of Practice and Theory, Vol. 34 No. 2, pp. 59-89.

Tarek, R.G. and Mohamed, G.A. (2016), "Corporate governance of UAE financial institutions: a comparative study between conventional and Islamic banks", Journal of Applied Finance and Banking, Vol. 6 No. 5, pp. 119-160.

Thomi, D.K. (2014), "The effect of Islamic banking products on financial performance of commercial banks in Kenya”, Doctoral Thesis, University of Nairobi, Collections: College of Humanities and Social Sciences (CHSS) [23318], available at: http://hdl.handle.net/11295/75430.

Thu, N.T.H., Hung, P.M. and Anh, N.T.L. (2016), "An empirical study of corporate governance and banks' performance in Vietnamese commercial banks", Journal of Management, Vol. 6 No. 2, pp. 87-114.

Vienot, M. (1995), "The board of directors of listed companies", Report of the CNPF-AFEP working group, French Association of Private Enterprises and CNPF, Paris.

Wan, A.W.A., Majella, P. and Jenny, S. (2010), "Corporate governance disclosure practices of Islamic banks: the case of Islamic banks in the Southeast Asian and the gulf cooperation council region", Working Paper.

Xie, B., Davidson, W. and DaDalt, P. (2003), "Earnings management and corporate governance: the role of the board and the audit committee", Journal of Corporate Finance, Vol. 9 No. 3, pp. 295-316.

Zalata, A., Tingbani, I. and Tauringana, V. (2018), "Audit committee financial expertise, gender, and earnings management: does gender of the financial expert matter?", International Review of Financial Analysis, Vol. 55 No. C, pp. 170-183.

\section{Appendix}

The Chow test was used to test the coefficient stability of the regression on two in-dependent samples through the comparison between the coefficients of two sets of linearly distributed data. The purpose of this test was to detect the presence of structural changes from breaks in data concentrations (Chow, 1960). The application of this test consisted firstly of estimating the two samples' regressions together in a single model, then, evaluating the two models separately for each of the two samples, and finally checking whether the coefficients of the two models were statistically different.

The steps of this test are outlined as follows:

(1) Collect the residual sum of squares (RSS) after estimation of the whole RSS mother population.

(2) Collect the residual sum of squares RSS1 and RSS2 on the basis of two samples of conventional and Islamic banks.

(3) Calculate the statistics of the test, following the Fisher law:

$$
F=\frac{\mathrm{RSS}-(\mathrm{RSS} 1+\mathrm{RSS} 2)}{\mathrm{RSS} 1+\mathrm{RSS} 2} * \frac{N-2 k}{k}=\frac{\frac{\mathrm{RSS}-(\mathrm{RSS} 1+\mathrm{RSS} 2)}{k}}{\frac{\mathrm{RSS} 1+\mathrm{RSS} 2}{N-2 k}} \cdots F \rightarrow(k, N-2 k)
$$

The statistics of the test follow Fisher's law of degrees of freedom $\nu 1=k$ and $\nu 2=N 1+N 2-2 k$, where $k$ is the number of explanatory variables including the constant and $N$ is the sum of the observations of two samples $N=(N 1+N 2)$, where $N 1$ is the total number of observations of the first sample and $N 2$ is the total number of observations of the second sample.

4-This test is based on Fisher's law, where if the calculated statistics $(F)$ are lower than the tabulated statistics, we reject the hypothesis of the stability of the coefficients. In this case, we conclude that there is a structural change and vice versa.

\section{About the authors}

Achraf Haddad is a Doctor of Financial and Accounting Methods. He is a researcher at a Laboratory of Economic Sciences at the Faculty of Economic Sciences and Management of Sousse, Tunisia. Moreover, 
he is a researcher at a Laboratory of Governance, Finance and Accounting at the Faculty of Economic Sciences and Management of Sfax, Tunisia. His research studies deal with finance, Islamic finance, accounting and governance. Achraf Haddad is the corresponding author and can be contacted at: achraf. haddad2015@gmail.com

Anis El Ammari is an Assistant Professor of Accounting and Finance at the Faculty of Economic Sciences and Management of Mahdia, Tunisia. He is now the Department Head of Accounting and Finance (University of Monastir, Tunisia) and a member of the International Academic Association of Governance (IAAG, France). The topic of his research activities deals with corporate finance, financial management and financial accounting.

Abdelfattah Bouri is a Professor of Finance at the Faculty of Economic Sciences and Management of Sfax, Tunisia. He is now the Department Head of Finance at the same faculty and the Director of Governance, Finance and Accounting Laboratory (University of Sfax, Tunisia). His works concern several areas of finance such as corporate finance, market finance, behavioral finance, Islamic finance, governance, entrepreneurship, statistics and econometrics. Moreover, he is also the author of many finance books.
The effect of audit committee quality

For instructions on how to order reprints of this article, please visit our website: 